\title{
WSPÓŁCZESNE ZAPYTYWANIE O DOBRO JAKO PYTANIE O CZŁOWIEKA
}

\section{Zarys problemu}

Pytanie: „Dlaczego istnieje raczej zło niż dobro?”1, którym Lévinas sparafrazował Leibniza, skłania do poczynienia trzech spostrzeżeń. Po pierwsze, okazuje się, że problematyka aksjologiczna nie jest odseparowana od sfery fundamentalnych zagadnień filozofii, lecz ją zakłada oraz dopełnia. Po drugie, problematyka ta, podobnie jak większość filozoficznych kwestii, nie straciła na aktualności. I wreszcie, po trzecie, wywoływanie jej nie może się dokonywać w dystansie od filozoficznej refleksji nad człowiekiem - również ta ostatnia przesłanka nie uległa historycznej dewaluacji. Zapewne też pytanie o dobro, stawiane $\mathrm{w}$ dobie współczesnej i ściśle korespondujące z filozoficznym pytaniem o człowieka, odsyłając do swoich historycznych precedensów, zarazem domaga się rewizji utartych sposobów problematyzowania dobra. Intencją tego pytania, niosącego w sobie niezbywalny komponent antropologiczny, musi być przewartościowanie filozoficznych przyzwyczajeń. Oto tradycyjna perspektywa poznawcza, faworyzująca abstrakcyjny podmiot poznania, wraz z wyobrażeniem o świecie pojmowanym jako uniwersum bytów ulegają zakwestionowaniu. Nie one są najważniejsze i nie one powinny nadawać ton filozoficznym poszukiwaniom, zwłaszcza jeśli ich tematem ma być człowiek, czyli ten, kto pyta o dobro, kto go doświadcza i żyje w jego horyzoncie bez możliwości zawieszenia go lub unieważnienia.

\footnotetext{
1 E. Lévinas, O Bogu, który nawiedza myśl, tłum. M. Kowalska, Kraków 1994, s. 207.
} 
Pytanie o dobro jest zatem szczególnym impulsem ku temu, by dokonać rewizji dotychczasowej optyki antropologicznej. Czyżby pytanie to nie posiadało własnej autonomii, nie odznaczało się specyfiką dystansującą je od ogólnej dziedziny pytań o byt, a jego eksplikacja powinna przebiegać wedle powszechnych zasad regulujących teoretyczne dociekania? Czy jego najwłaściwszym kształtem jest struktura podmiotowo-orzecznikowa, formalizująca poznawczą ciekawość i standardowa dla większości zadawanych przez nas pytań? Czy powinniśmy poddać je dyscyplinującemu schematowi, przewidzianemu dla pytań filozoficznych, a zwłaszcza naukowych?

Pytanie o dobro, stawiane $\mathrm{w}$ dziejach filozofii, najwyraźniej uobecniło się w obszarze aksjologii, ale przecież patronowało także, przynajmniej implicite, ontologii oraz teorii poznania. Wydaje się jednak, że dopiero w obrębie myśli współczesnej ujawniło ono w sposób wyraźny swoją antropologiczną doniosłość. Można przyjąć, że ludzka zdolność do otwierania się na dobro, do "rozumienia się" na nim, do życia w jego świetle i w jego horyzoncie to specyficzne wyznaczniki naszej egzystencji. Nasze istnienie niewątpliwie przebiega pod znakiem „myślenia według wartości”. A to z kolei odsyła do dobra, zmusza do określenia jego statusu: względem wartości, względem nas i w kontekście świata, będącego czymś więcej aniżeli zbiór środowisk zamieszkiwanych przez żywe istoty.

Szczególnie wyczulona na ten aksjologiczny, a właściwie agatologiczny wymiar ludzkiego egzystowania wydaje się współczesna filozofia dialogu oraz wyrastająca z niej „filozofia dramatu” księdza Józefa Tischnera. Dobro, podobnie jak prawda o nim, oraz wolność, niezbędna, by je urzeczywistniać, decyduje o niezbywalnej jakości ludzkiego życia. Zarazem dobro ujawnia $\mathrm{w}$ człowieku tego, kto transcenduje potrzeby $\mathrm{w}$ kierunku pragnień. Bo chociaż życie ludzkie przebiega w czasoprzestrzennym "tu i teraz", diagnozowanym z uwagi na spektrum potrzeb, to jednak fenomen dobra odsyła do bezinteresowności, wolności oraz do swego transcendentnego, pozakulturowego źródła².

\section{Zło jako trampolina dobra}

Tłem ludzkiego obcowania $\mathrm{z}$ dobrem jest rozpoznawanie zła, a nawet jego doświadczanie. Ta sytuacja jest zapewne komponentem ludzkiej historii, w której i poprzez którą człowiek doświadcza swojego istnienia.

2 Por. W.P. Glinkowski, Człowiek - istota spoza kultury. Dialogika Martina Bubera jako podstawa antropologii filozoficznej, Łódź 2011. 
O wkroczeniu w tę historię opowiada biblijna Księga Rodzaju. Oto, mimo podobieństwa do Boga, sytuacja człowieka stającego wobec dobra i zła jest diametralnie odmienna. "Człowiekowi - jak pisze Martin Buber - stworzonemu, ale nie uczestniczącemu w stwarzaniu [...] - odmówiono, pomimo jego bycia [...] na obraz i podobieństwo Boga, władczego rozporządzania [überlegen-vertrautes] przeciwieństwami [Gegensätze]"3. Człowiek nie jest twórcą zasady przeciwieństw, lecz kimś, kto doświadcza jej jako polaryzacji i dysjunkcji. Osiąganie wrażliwości w zakresie rozpoznawania dobra i zła jest procesem zakładającym inicjację i wymagającym od człowieka szczególnego wysiłku. Ceną będzie wykluczenie z pierwotnej harmonii, wprawdzie doskonałej, ale - jak się okaże z perspektywy późniejszych aksjologicznych doświadczeń - niekompletnej. Wygnanie jest dla człowieka karą, ale też błogosławieństwem: „z m i e j s c a , które było mu przygotowane, z o s t a je wysłany w drogę - jego, ludzką drogę [podkr. W.G.]"4. Dobro objawi się człowiekowi w pełni jako utracone i względnie niedostępne; jako zagrożone przez zło i dopiero teraz - upragnione. I, paradoksalnie, „ziemia wygnania", czyli świat ujawniający horyzont zła, otworzy zarazem h o r y zont dobra.

Ludzki świat, „najlepszy z możliwych”, to świat, w którym dobro może i powinno być rozpoznane, doświadczone oraz przeżyte - $w$ którym zostanie uznane za najcenniejsze. Jednak $\mathrm{w}$ takim świecie dobro dość powszechnie pojawia się $w$ cieniu zła będącego jego przeciwieństwem. Oczywiście, zło moralne nie jest ani ontyczną kontradykcją, ani paralelą dobra. Nie przysługuje mu realność, stanowi co najwyżej omisio lub privatio, jak nauczał św. Augustyn ${ }^{5}$. Przychodzi jako zjawa, zła nowina. Bywa skandalem - zwłaszcza dla tych, którzy skłonni są zamykać się w immanencji bytowego "tu i teraz". A jednak, w planie ludzkiego poznania pełni istotną rolę, niczym cień względem obiektu, od którego powstaje i którego realności pośrednio dowodzi; jest jak rewers, dopełniający monetę i czyniący ją prawdziwą, albo jak cisza udzielająca dźwiękom przestrzeni, by rozbrzmiewały. To dlatego w żydowskiej tradycji zwrot „z całego serca swego i z całej duszy swojej” bywa tłumaczony jako „obiema skłonnościami - dobrą i złą [jecer tow i jecer hara]". Chodzi tu nie o to, by zlikwidować zły popęd, lecz o to, by mocą miłości poddać go Bogu. Dopiero w obliczu zła człowiek poddany zostaje próbie jako beneficjent dobra, ale też jako jego świadek. Zło prowokuje nas do

${ }^{3}$ M. Buber, Bilder von Gut und Böse, [w:] idem, Werke, Bd. I: Schriften zur Philosophie, München - Heidelberg 1962, s. 614.

${ }^{4}$ Ibidem, s. 617.

${ }^{5}$ Czytamy: „zła wola - to nie wytworzenie, lecz odstąpienie”; św. Augustyn, O państwie Bożym, t. II, tłum. W. Kornatowski, Warszawa 1977, s. 58. 
przemyślenia jego granic, byśmy mogli - wzorem Hioba - doskonalić się w odróżnianiu go od tego, co mimo pozorów, nie jest rzeczywistym złem.

Jednak zło, będące niedającym się pominąć kontrapunktem dobra, nie powinno być bezkarne. Może kusić, ale nie łudzić, jak pisze Buber w swoim Gogu i Magogu ${ }^{6}$. Nie wolno mu się plenić, a tym bardziej deptać zastany porządek wartości lub próbować ogłosić własny. Wprawdzie jest ono, jak zauważa Tischner, „bliższe naszym doświadczeniom”, bo towarzyszy naszemu byciu w świecie, jednak tym, co "bliższe naszym pragnieniom”, jest dobro. To ono potrafi obudzić pragnienia. To ono gwarantuje ich ważność i pozwala nam wierzyć, że nie są one sprowadzalne do potrzeb. To dlatego słowo "potrzeba”, choć funkcjonuje w przestrzeni aksjologicznej, nie zapewnia rozpoznania człowieczeństwa - własnego i innych - i uznania statusu bycia osobą.

Czy jednak dobro i zło są uogólnieniami czegoś szczegółowego, doświadczanego, różnie nazywanego i manifestującego się wielorako? Czy jedyną legitymizacją dobra miałyby być wartości, do których dobro odsyła? I, odpowiednio, czy zło miałoby zaświadczać o jakiejś "zmazie”, "plamie" lub innym z licznych dyskomfortów, które, choć niechciane, niezmiennie sekundują ludzkiemu doświadczeniu? A może jest odwrotnie? Może wartości są zaledwie egzemplifikacjami dobra, jedynego i źródłowego. Albo, inaczej mówiąc, nie dobro jest „wartościowe”, lecz wartości, w różnym stopniu i rozmaicie, w sposób sobie właściwy, "są dobre” - mają swój drobny udział w dobru - reprezentują je, świadczą o nim, czynią je „widzialnym”, czy raczej „słyszalnym”, dostępnym człowiekowi.

\section{Pozautylitarna ranga dobra}

Dobro nie jest czymś, czego potrzebujemy, gdyż w przeciwnym razie stałoby się "dobrem użytkowym”, przedmiotem, towarem, czymś, czym można zawładnąć, rozporządzać. Przeciwnie, dobro jest i musi pozostać tym, co upragnione, święte, transcendentne. Przy czym jego transcendencja nie może być rozumiana inaczej niż jako bezprecedensowa, pierwsza, poprzedzająca realność świata i realność mojego własnego Ja. Wszak Inny jak naucza Lévinas - „nie jest negacją Toż-Samego”, podobnie jak zewnętrzność, która „nie jest negacją, lecz cudem”7.

${ }^{6}$ M. Buber, Gog i Magog. Kronika chasydzka, tłum. J. Garewicz, Warszawa 1998, s. 34.

7 E. Lévinas, Całość i nieskończoność. Esej o zewnętrzności, tłum. M. Kowalska, Warszawa 1998, s. 369 i 351. 
Dobra nie można mierzyć, gdyż ono samo jest miarą. Niepodobna orzekać o nim, lecz jedynie według niego. Ignorowanie pytania o dobro jest tożsame z przekreśleniem tego, co stanowi o naszym człowieczeństwie. Wrażliwość na dobro i wrażliwość na bycie człowiekiem pozostają nierozerwalnie ze sobą splecione. Poszukiwanie utylitarnych racji na rzecz rozpoznawania dobra i czynienia go byłoby nieporozumieniem: „Nie czynimy dobra, ponieważ jest ono wartością lub ze względów praktycznych, lecz ponieważ jesteśmy Bogu za nie wdzięczni"8. Dopóki redukujemy sens dobra do poziomu utylitarnego, dopóty mówimy o czymś innym niż o Dobru. Bo, jak poucza Robert Spaemann, rzetelne rozpoznanie sensu orzeczenia "dobry" zakłada, że wykracza on poza sens bycia dobrym „do czegoś" 9 .

Dobro nie jest korelatem którejkolwiek z ludzkich potrzeb (np. estetycznej lub poznawczej), gdyż wciąż odsyła do pragnienia i nadziei i w ten sposób jest przeżywane. Prowokuje do nieustawania w szukaniu go i zbliżaniu się ku niemu, a nie do tego, by zadośćuczynić naszym oczekiwaniom będącym wyrazem stwierdzenia ontycznego braku.

Dobro jest chyba jedynym argumentem za tym, że ludzkie życie nie poddaje się subsumcji do przestrzeni kultury. Życie człowieka nie wyczerpuje się bowiem $\mathrm{w}$ żadnej z gier organizujących kulturowe uniwersum. Nie jest ono także ich sumą, toteż niepodobna jego rozumienia wyprowadzać z rozumienia dynamiki ról odgrywanych w społeczno-kulturowej rzeczywistości - wbrew temu, co głosił Erving Goffman ${ }^{10}$.

Zrozumieć dobro można pod warunkiem uczestnictwa w dramatycznych interakcjach, zawiązujących się między ludźmi i będących jakimś refleksem interakcji między człowiekiem i Bogiem. Deprecjonowanie tego wspólnotowego wymiaru ludzkiej egzystencji Edyta Stein zarzucała Heideggerowi, który ponadto „myślenie według wartości” zaliczał do kardynalnych uchybień względem prawdy bycia ${ }^{11}$.

Nawiązujący do Heideggera Michael Landmann wskazał w swej antropologii fundamentalnej na podstawowe wyróżniki, „antropina”, mające organizować filozoficzne myślenie o człowieku ${ }^{12}$. Czy jednak szczególne miejsce wśród nich nie powinno przypaść dobru?

8 A.J. Heschel, Bóg szukający człowieka, tłum. A. Gorzkowski, Kraków 2007, s. 466.

${ }^{9}$ R. Spaemann, O pojęciu natury ludzkiej, tłum. Z. Krasnodębski, [w:] Człowiek w nauce wspótczesnej. Rozmowy w Castel Gandolfo, red. K. Michalski, Kraków 2006, s. 109.

${ }^{10}$ E. Goffman, Człowiek w teatrze życia codziennego, tłum. H. Datner-Śpiewak, P. Śpiewak, Warszawa 2000.

${ }_{11}$ M. Heidegger, List o humanizmie, tłum. J. Tischner, [w:] idem, Znaki drogi, Warszawa 1995, s. 157.

12 M. Landmann, Fundamental-Anthropologie, Bonn 1979, s. 77-92. 
Uwzględnienie kondycji współczesnej filozofii, zwłaszcza w szerszym kulturowym kontekście, pozwala założyć, że pytanie o dobro podzieliło los pytania o człowieka. Oba stały się wstydliwe, archaiczne, niezręczne. Oba uległy przyćmieniu, które zapewne pozostaje nie bez związku z zaćmieniem człowieczeństwa albo zaćmieniem Boga, rozpoznawanymi choćby przez dwudziestowiecznych dialogików, jak Buber czy Heschel ${ }^{13}$.

\section{Imienny fenomen dobra}

"Czy Dobro musi «najpierw» być, żeby być dobre?" - pyta Tischner. Autor ten, w swej refleksji nad dobrem, ponad porządkiem bytu stawia porządek wartości. Te z kolei wyprowadza z dobra, którego ethos jest ważniejszy i wcześniejszy od wszelkiego logosu. W ten sposób aksjologia zostaje ugruntowana w agatologii, z której się wywodzi i która ją uzasadnia, usprawiedliwia ${ }^{14}$. Namysł nad dobrem rehabilituje ludzką jednostkę, a wraz $\mathrm{z}$ nią to, czego filozofia nie darzyła szacunkiem i czemu przeciwstawiała "całość", pojmowaną jako bytujące ponad czasem i przestrzenią uniwersum. Czytamy: „To dobroć udziela subiektywności jej nieredukowalnego znaczenia"15. Podążając tym tropem, można tu dopowiedzieć, że dzięki dobru rodzi się osoba, która jest czymś całkiem innym niż grecka maska-prosophon. Osoba nie jest już aktorem, jednym z wielu, odgrywającym dramatyczne role, lecz staje się rzeczywistym podmiotem dramatu. Jest to dramat spotkań i rozstań, wyborów pomiędzy wartościami, które nieraz pozostają ze sobą $\mathrm{w}$ konflikcie. Ten dramat nie rozgrywa się w przestrzeni kulturowych artefaktów, lecz w świetle dobra i zła. Rozróżnianie między nimi jest fundamentem ludzkiego rozeznawania się w świecie. To one są i pozostają rzeczywistym kryterium ludzkiego ocalenia lub potępienia.

Człowiek ma dostęp do dobra, podobnie jak do słowa - jest ich słuchaczem. Ludzka reakcja na dobro zakłada raczej słyszenie niż widzenie. Żeby usłyszeć słowo, trzeba się na nie otworzyć - być capax Dei, by użyć formuły funkcjonującej w obrębie antropologiczno-transcendentalnej perspektywy

${ }^{13}$ M. Buber, Zaćmienie Boga, tłum. P. Lisicki, Warszawa 1994; A.J. Heschel, Kim jest człowiek?, tłum. K. Wojtkowska, Łódź - Warszawa 2014, s. 59-62.

14 Wyższość zasady dobra względem zasady istnienia mają oddać słowa: „To nie bycie usprawiedliwia dobro, lecz dobro usprawiedliwia bycie" (J. Tischner, Spór o istnienie człowieka, Kraków 1998, s. 187). Nietrudno tu rozpoznać aluzję do tytułowego „inaczej niż być” znanego książki E. Lévinasa.

15 J. Tischner, Filozofia dramatu, Paryż 1990, s. 52. 
współczesnego teologa ${ }^{16}$. Dobro, które mnie wzywa i na które się otwieram, czyni mnie beneficjentem nieskończoności wypełniającego je sensu. Lévinas upatruje $\mathrm{w}$ nim Dobroć. To ona ucieleśnia się w twarzy Innego. Właśnie przez nią przemawia i w ten sposób zaświadcza o „obecności Nieskończonego". Dobro wymyka się uzasadnieniu. Wedle Lévinasa, jest „an-archiczne”, gdyż poprzedza wszelkie archai-zasady i samo stanowi ostateczne ich uzasadnienie. Jest też archontyczne, bo nie pozwala się zamknąć w idei, choćby nawet regulatywnej, a jego rozpoznawanie kieruje ku rzeczywistości międzyosobowej. W obliczu dobra, Ja pozostaje bierne; jest wszak wybierane: „niedobrowolnie, bez swojego udziału” 17 . Ale jest równocześnie czynne, bo odpowiada: staje na wezwanie Drugiego jako odpowiedzialne - absolutnie i bezwarunkowo. W ten sposób daje świadectwo - jemu, o nim, wobec niego.

Siedzibą Dobra nie jest grecki Olimp, a jego miary nie wyczerpuje doskonałość, gdyż uobecniająca się w nim świętość transcenduje wszelką wymierność. Również Bóg znany tradycji judeochrześcijańskiej nie jest „nieruchomym Poruszycielem", przykrojonym wedle wyobrażeń o greckim logosie. Jest raczej „najbardziej poruszonym”18, bo zabiega o ludzką miłość, jest zatroskany o człowieka19. Dobro nie jest atrakcją, taką jak doskonały byt, ku któremu kieruje się grecka myśl. To raczej ono samo kieruje się ku człowiekowi - bezinteresownie go wybiera, powołuje i zachęca do udzielenia odpowiedzi na swoje wezwanie.

Nie tylko perspektywa proponowana przez naturalizm, ale także postulowana przez fenomenologię nie prowadzi do eksplikacji Dobra. W pierwszej, jego transcendencja zostaje zakwestionowana, w drugiej - ulega osłabieniu przez podporządkowanie relacji poznawczej i, w rezultacie, subsumcji do sfery subiektywności. Dobro z pewnością jest fenomenem, jednak nieredukowalnym do tych, o których pisali Kant czy Husserl. Wprawdzie pojawia się w jakimś czasie i przestrzeni - jakże jednak różnych od tych, które użyczają formalnych ram naszemu teoretycznemu poznaniu. Jego czas jest czasem dramatycznym, trwającym między prośbą, etycznym roszczeniem, a odpowiedzią; między przykazaniem - wypowiedzianym i usłyszanym a jego wysłuchaniem i wypełnieniem. Podobnie przestrzeń dobra nie poddaje

16 "Człowiek jest słuchającym mowy bądź milczenia Boga w takim stopniu, w jakim otwiera się on na orędzie mowy bądź milczenia Boga objawienia"; K. Rahner, Stuchacz Słowa, tłum. R. Samek, Kęty 2008, s. 94-95.

17 E. Lévinas, Inaczej niż być lub ponad istota, tłum. P. Mrówczyński, Warszawa 2000, s. 32.

18 W. Szczerbiński, Abrahama Joshuy Heschela filozofia człowieka, Lublin 2000, s. 114.

19 A.J. Heschel, Człowiek nie jest sam, tłum. K. Wojtkowska, Kraków 2008, s. 115-128. Wedle Heschela, pasywność Boga, tak ważna w myśli greckiej, uwłaczałaby Jego godności; zob. idem, Prorocy, tłum. A. Gorzkowski. Kraków 2014, s. 414-445. 
się interwałom znanym fizyce lub matematyce. I nawet kosmos, choć „uładzony", nie dostarcza mu wiarygodnego uzasadnienia. Bowiem tym, co owa przestrzeń objawia, jest rzeczywistość międzyosobowa - realniejsza od tamtej, choć niewidzialna i niemierzalna. Przestrzeń dobra - podobnie jak jego czas - uzdalniają nas do „bycia wobec”, do wejścia w sferę Pomiędzy (Buberowskie Inzwischen), do otwarcia się na czyjąś obecność dla nas, a także do jej odwzajemnienia. Daremne byłoby szukanie precedensów dla takiej obecności w sferze bytów - zobiektywizowanych i podległych symbolicznym formom czasu i przestrzeni, lecz bezimiennych.

Odnajdywane we współczesnych nurtach filozoficznych dialogiczne i dramatyczne koncepcje dobra, jak również zła, sytuują je w przestrzeni międzyosobowej. Poza nią dobro i zło ulegają wirtualizacji, stają się nie tylko abstrakcyjnymi quasi-obiektami, a próby ich problematyzacji niejednokrotnie prowadzą na manowce spekulatywnego myślenia. Tymczasem najdonioślejsza prawda o dobru odsłania się nie w spektrum bytów ani nie w kontradykcji do abstrakcyjnego zła, lecz w sferze międzyosobowych odniesień. Dobro nie jest abstrakcyjnym bytem, lecz tym, co przynosi ocalenie. Zło nie jest „brakiem bytu” lub niedostatkiem dobra. To nie znaczy, że jest ono iluzją, przeciwnie - jest najbardziej realne właśnie jako niesprowadzalne do zwykłego cierpienia, bo przychodzące w postaci „złego posłańca”, mające źródło w złej intencji. Racją dobra jest bezinteresowna decyzja, akt wybrania do relacji, gest zaproszenia do partnerstwa ${ }^{20}$. Przyczyną zła nie jest błąd intelektu, jakaś epistemologiczna „nieprawda”, lecz zły wybór, będący owocem kłamstwa.

Stawianie pytań o Dobro daleko wykracza poza obszar teoretycznych dociekań. I niezależnie od rangi, jaką gotowi jesteśmy mu przyznać, wpisuje się w naszą egzystencję w sposób określający jej sens, wartość, autentyczność. Zasadniczym powodem stawiania tych pytań jest zatem nie tyle roszczenie do teoretycznego rozstrzygania kwestii genezy Dobra lub jego ontycznego statusu, ile nadzieja na poszerzenie naszego filozoficznego namysłu i pogłębienie etycznej wrażliwości ${ }^{21}$. Konsekwencją ich zaniedbania, zagubienia ich intencji, jest nieuchronna deformacja perspektywy,

20 Por. E. Stawnicka-Zwiahel, Stworzeni do relacji. Dialogiczne inspiracje Martina Bubera, Toruń 2012

${ }^{21}$ Chciałoby się powtórzyć słowa polskiego filozofa, mające odsłonić praktyczny i etyczny sens pytania o dobro: „Dobro nie wymaga ode mnie, abym akceptował jego istnienie. Dobro wymaga ode mnie, abym dał chleb głodnemu. [...] A zatem istnienie czy nieistnienie takiego bytu jak Dobro nie wpływa w żaden sposób na moje zachowanie wobec drugiego człowieka"; J. Tischner, Uprawiam filozofie dobra, [w:] Rozmowy o filozofii, red. A. Zieliński, M. Bagiński, J. Wojtysiak, Lublin 1996, s. 261. 
w której rozpoznajemy siebie. Bo przecież Dobro jest owym głosem, który „przebija się przez hałasy świata, aby wezwać człowieka do czegoś absolutnego" 22 .

\section{Contemporary Polling on Good as a Question on Man}

\section{Summary}

Axiological topics, especially the concept of right and good and questions concerning nature of good, are intrinsic part of philosophy of men. This can be observed in contemporary philosophical tendencies, in particular those originated from philosophy of dialogue. In this perspective the emphasis in question of good moves from ontology to the philosophical anthropology. Good turns out to be interpersonal phenomenon, which is cohere with mutual dialogue and the drama of human existence, rather than with a "scene" understood as noumenal universe. Interesting notion of such philosophical approach to good can be found in thought of contemporary philosophers of dialogue and Józef Tischner's concept of philosophy of drama.

22 J. Tischner, Filozofia dramatu, op. cit., s. 91. 